\title{
Animal performance and nutrient digestibility of feedlot steers fed a diet supplemented with a mixture of direct-fed microbials and digestive enzymes
}

\author{
Christian Michael Alvarez Encinas ${ }^{1}$, Guillermo Villalobos Villalobos ${ }^{1}$, Joel Domínguez \\ Viveros $^{1}$, Gabriela Corral Flores ${ }^{1}$, Enrique Alvarez Almora ${ }^{2}$, Francisco Castillo Rangel ${ }^{1 *}$ \\ 1 Universidad Autónoma de Chihuahua, Facultad de Zootecnia y Ecología, Chihuahua, Chihuahua, México. \\ ${ }^{2}$ Universidad de Baja California, Instituto de Ciencias Agrícolas, Mexicali, Baja California, México.
}

\begin{abstract}
The objective of this study was to evaluate the effect of a mixture of direct-fed microbials (DFM), yeast, and digestive enzymes on animal performance in feedlot cattle, as well as digestibility when finishing feedlot cattle. Thirty crossbreed (Charolais $\times$ Beefmaster) steers averaging 15 months old and $321.83 \pm 3.73 \mathrm{~kg}$ of initial body weight were used. Animals were randomly assigned to one of two treatment groups: control (basal diet) and a mixture of DFM, yeast, and digestive enzymes (basal diet $+30 \mathrm{~g}$ of the mixture). Each group contained fifteen experimental units. Animals were fed individually twice a day, and dry matter intake (DMI) was recorded daily. Body weights were recorded initially and subsequently at 28-day intervals for a total of 140 days to evaluate average daily gain (ADG). The gain:feed ratio (G:F) was also calculated per period. Dry matter digestibility, crude protein (CPD), and neutral detergent fiber (NDFD) were evaluated in the finishing phase. Ten steers per treatment were randomly selected for digestibility evaluations. Insoluble acid detergent fiber was used to calculate apparent digestibility. A completely randomized design with measurements repeated over time was used to evaluate animal performance, and a completely randomized design was used to evaluate apparent digestibility. No effect of treatment was observed for DMI. At the end of the trial, differences for ADG were found between treatments, with higher values in control than the treatment group. However, no effect for G:F was found. Dry matter digestibility, CPD, and NDFD were similar between treatments. The addition of the mixture of DFM, yeast, and digestive enzymes as a feed supplement in the diet of feedlot cattle does not improve animal performance and nutrient digestibility.
\end{abstract}

Key Words: enzymes, finishing, probiotics, Saccharomyces cerevisiae, yeast

\section{Introduction}

Feedlot cattle system is a common and important technique for meat production in Mexico. Feedlot activity is a major source of meat, which is considered a highly nutritious and valued food (Scollan et al., 2006), which are important characteristics for consumers and producers, respectively. Phelps et al. (2015) proposed that the goal of the beef industry is to produce a consistent, high-quality product as efficiently as possible. Different animal nutrition strategies, such as the use of different additives (AvendañoReyes et al., 2006; Bryant et al., 2010; Thompson et al., 2016), are practiced to increase efficiency in the feedlot.

Recently, concern about the use of antibiotics and other substances in animal feed has increased. For this

Received: June 1, 2017

Accepted: May 1, 2018

*Corresponding author: fcastillor@uach.mx

Copyright (C) 2018 Sociedade Brasileira de Zootecnia. This is an Open Access article distributed under the terms of the Creative Commons Attribution License (http://creativecommons.org/licenses/by/4.0/), which permits unrestricted use, distribution, and reproduction in any medium, provided the original work is properly cited. reason, the use of direct-fed microbials (DFM) has been considered as a strategy for finishing feedlot cattle (Elam et al., 2003). Fuller (1989) defined probiotics as live supplements that benefit the host animal by improving its intestinal microbial balance. However, this definition does not consider the pre-existing ruminal microbial population. To address this deficiency, Kmet et al. (1993) defined ruminal probiotics as live cultures of microorganisms that are deliberately introduced into the rumen aiming at improving animal health or nutrition. The terms probiotics and DFM are often used interchangeably.

Probiotics are classified as viable microbial cultures, enzyme preparations, culture extracts, or combinations of the above (Yoon and Stern, 1995), and include both fungal and bacterial cultures (Krehbiel et al., 2003). Depending on the bacteria strain, they are classified as lactate acidproducing, lactate acid-utilizing, or other microorganisms (Seo et al., 2010).

When lactate acid-producing or lactate acid-utilizing bacteria are added to feedlot cattle diets, their use has been shown to improve feed efficiency (G:F) and daily 
gain (Galyean et al., 2000). It has been assumed that the presence of these strains of bacteria can encourage the adaptation of ruminal microorganisms to the presence of lactic acid, expediting its utilization (Yoon and Stern, 1995). Another theory holds that the production responses attributed to yeast are related to the stimulation of cellulolytic and lactate-utilizing bacteria; these responses include increased fiber digestion and microbial protein flow from rumen (Martin and Nisbet, 1992; Newbold et al., 1996).

Krehbiel et al. (2003) reported that the use of probiotics in animal feeding increases average daily gain (ADG) by 2.5 to $5 \%$ and G:F by $2 \%$ in feedlot cattle compared with a control group. Nonetheless, the results reported in the literature are inconsistent. Little information is available about the use of a mixture of DFM, yeast, and digestive enzymes on feedlot cattle. The objective of this study was to evaluate the effect of a mixture of DFM, yeast, and digestive enzymes on animal performance in feedlot cattle and on feed digestibility during the finishing process.

\section{Material and Methods}

All procedures involving animals were in accordance with both local official techniques for animal care (NOM051-ZOO-1995: Humanitarian care of animals during mobilization; NOM-024-ZOO-1995: Animal health stipulations and characteristics during transportation) and the institutional code for Bioethics Regulation of Animal Welfare (case number: CFTZyE-ACTA-101/2015: ACUERDO 4.2).

The experiment was performed in Tepatitlán de Morelos, Jalisco, Mexico (2047'46.1" N, 10241'20.7" W, and 1,880 m altitude) from February to July, 2016. Thirty crossbreed (Charolais $\times$ Beefmaster) steers averaging 15 months old and $321.83 \pm 3.73 \mathrm{~kg}$ initial body weight (BW) were used. At the beginning of the experiment, all steers were identified, vaccinated for Clostridium chauvoei, $C$. septicum, C. novyi, C. sordelli, C. perfringens, Pasteurella haemolytica, and P. multocida A and D (Bacterina toxoide 8 vías; Laboratorios Pier S. A. de C. V.; Puebla, México), treated for internal and external parasites with ivermectin (Ivomec; Merial de México S. A. de C. V.; Querétaro, México), implanted (200 $\mathrm{mg}$ of trenbolone acetate and $28 \mathrm{mg}$ estradiol benzoate; MaxiChoice 200; Lapisa S. A. de C. V.; Michoacán, México), and given vitamin A, D, and E supplements. Animals received a second vaccination and implant on day 84. Steers were kept outdoors in individual pens $\left(13 \mathrm{~m}^{2}\right)$ and were randomly assigned to one of two treatments. Treatments consisted of control (basal diet;
Table 1) and a mixture of DFM, yeast, and digestive enzymes (DFM; basal diet $+30 \mathrm{~g}$ animal $^{-1}$ day $^{-1}$ of the additive) (Tables 1 and 2). Fifteen experimental units were considered for each treatment. Across the experiment, three diets were provided (Table 1). Animals were fed individually twice a day (07:00 and 17:00 h) with an adjustment based

Table 1 - Ingredients and calculated chemical composition (DM basis) of diets

\begin{tabular}{|c|c|c|c|}
\hline Ingredient & $\begin{array}{c}\text { Phase } 1 \\
\left(\mathrm{~g} \mathrm{~kg}^{-1} \text { of }\right. \\
\mathrm{DM})\end{array}$ & $\begin{array}{c}\text { Phase } 2 \\
\left(\mathrm{~g} \mathrm{~kg}^{-1} \text { of }\right. \\
\mathrm{DM})\end{array}$ & $\begin{array}{c}\text { Phase } 3 \\
\left(\mathrm{~g} \mathrm{~kg}^{-1} \text { of }\right. \\
\text { DM) }\end{array}$ \\
\hline Corn silage & 263.4 & 175.0 & - \\
\hline Corn stover & 200.0 & 158.5 & 253.1 \\
\hline Ground corn grain & 356.8 & 476.3 & 675.0 \\
\hline Dry distillers grains & 115.4 & 149.2 & 20.0 \\
\hline Soybean meal & 50.0 & 30.0 & 30.0 \\
\hline Mineral premix ${ }^{1}$ & 9.4 & 6.0 & 5.0 \\
\hline Calcium carbonate & 5.0 & 5.0 & 5.0 \\
\hline Magnesium oxide & - & - & 5.0 \\
\hline Sodium bicarbonate & - & - & 5.0 \\
\hline Sodium chloride & - & - & 1.9 \\
\hline \multicolumn{4}{|c|}{ Calculated chemical composition } \\
\hline $\mathrm{DM}\left(\mathrm{g} \mathrm{kg}^{-1}\right.$ as fed $)$ & 581.0 & 657.8 & 876.1 \\
\hline $\mathrm{NE}_{\mathrm{m}}\left(\mathrm{Mcal} \mathrm{kg}^{-1}\right)$ & 1.82 & 1.93 & 1.93 \\
\hline $\mathrm{NE}_{\mathrm{g}}\left(\mathrm{Mcal} \mathrm{kg}{ }^{-1}\right)$ & 1.19 & 1.28 & 1.28 \\
\hline $\mathrm{CP}\left(\mathrm{g} \mathrm{kg}^{-1}\right.$ of $\left.\mathrm{DM}\right)$ & 120.0 & 120.0 & 100.5 \\
\hline $\mathrm{Ca}\left(\mathrm{g} \mathrm{kg}^{-1}\right.$ of $\left.\mathrm{DM}\right)$ & 5.5 & 4.6 & 3.4 \\
\hline $\mathrm{P}\left(\mathrm{g} \mathrm{kg}^{-1}\right.$ of $\left.\mathrm{DM}\right)$ & 3.2 & 3.1 & 2.8 \\
\hline $\mathrm{K}\left(\mathrm{g} \mathrm{kg}^{-1}\right.$ of $\left.\mathrm{DM}\right)$ & 8.1 & 6.7 & 6.9 \\
\hline $\mathrm{EE}\left(\mathrm{g} \mathrm{kg}^{-1}\right.$ of DM$)$ & 39.0 & 43.5 & 34.6 \\
\hline DE $($ Mcal kg-1) & 3.30 & 3.46 & 3.43 \\
\hline ME (Mcal kg ${ }^{-1}$ ) & 2.70 & 2.84 & 2.81 \\
\hline $\mathrm{TDN}\left(\mathrm{g} \mathrm{kg}^{-1}\right.$ of DM$)$ & 729.0 & 760.1 & 743.0 \\
\hline $\mathrm{NDF}\left(\mathrm{g} \mathrm{kg}^{-1}\right.$ of DM) & 350.1 & 302.5 & 239.0 \\
\hline
\end{tabular}

$\mathrm{DM}$ - dry matter; NE - net energy of maintenance; $\mathrm{NE}$ - net energy of gain; $\mathrm{CP}$ crude protein; EE - ether extract; DE - digestible energy; ME - metabolizable energy; TDN - total digestible nutrients; NDF - neutral detergent fiber.

${ }^{1}$ Mineral premix: CP, $200 \mathrm{~g} \mathrm{~kg}^{-1}$; Ca, $200 \mathrm{~g} \mathrm{~kg}^{-1}$; P, $15 \mathrm{~g} \mathrm{~kg}^{-1}$;, $4 \mathrm{~g} \mathrm{~kg}^{-1}$, $\mathrm{Mg}, 6.5 \mathrm{~g} \mathrm{~kg}^{-1} ; \mathrm{Na}, 50 \mathrm{~g} \mathrm{~kg}^{-1} ; \mathrm{S}, 0.9 \mathrm{~g} \mathrm{~kg}^{-1} ; \mathrm{Cu}, 11 \mathrm{mg} \mathrm{kg}{ }^{-1} ; \mathrm{Fe}, 314 \mathrm{mg} \mathrm{kg} \mathrm{g}^{-1}$ $\mathrm{Mn}, 14 \mathrm{mg} \mathrm{kg}^{-1} ; \mathrm{Zn}, 24 \mathrm{mg} \mathrm{kg}^{-1}$; I, $0.08 \mathrm{mg} \mathrm{kg}^{-1} ; \mathrm{Co}, 0.5 \mathrm{mg} \mathrm{kg}{ }^{-1} ; \mathrm{Se}, 0.2 \mathrm{mg} \mathrm{kg}{ }^{-1}$; vitamin A, $48 \mathrm{IU} \mathrm{g}^{-1}$; vitamin D, $200 \mathrm{IU} \mathrm{g}^{-1}$; vitamin E, $0.17 \mathrm{IU} \mathrm{g}^{-1}$.

Table 2 - Composition of the mixture

\begin{tabular}{lc}
\hline Ingredient & Quantity $^{1}$ \\
\hline Amylase (units) & 3,000 \\
Protease (units) & 400 \\
Cellulose (units) & 160 \\
Lipase (units) & 120 \\
Peptinase (units) & 80 \\
Lactase (units) & 1.8 \\
Lactobacillus acidophilus $(\mathrm{cfu})$ & $3.6 \times 10^{7}$ \\
Bifidobacterium thermopilum $(\mathrm{cfu})$ & $3.6 \times 10^{7}$ \\
Bifidobacterium longum $(\mathrm{cfu})$ & $3.6 \times 10^{7}$ \\
Enterococcus faecium $(\mathrm{cfu})$ & $3.6 \times 10^{7}$ \\
Saccharomyces cerevisiae $(\mathrm{cfu})$ & $8 \times 10^{6}$ \\
\hline
\end{tabular}

cfu - colony-forming units.

${ }^{1}$ Quantity of direct-fed microbials, yeast, and digestive enzymes for each $30 \mathrm{~g}$ of product. 
on refusal from 50 to $100 \mathrm{~g} \mathrm{~kg}^{-1}$ as fed. At the beginning of the experiment, animals underwent an adaptation period of 15 days to adapt to the diet. Diets were mixed daily and contained at least 120,120 , and $100.5 \mathrm{~g} \mathrm{~kg}^{-1}$ of crude protein (CP) and 1.19, 1.28, and 1.28 Mcal of net energy gain for each phase, respectively (NRC, 2000). Animals were allowed free access to water. In the last period (28 days), zilpaterol hydrochloride (Grofactor, Virbac México S. A. de C. V.; Jalisco, Mexico; $0.15 \mathrm{mg} \mathrm{kg}^{-1}$ of BW) and buffers (Table 1) were added to the control diet.

Body weights were recorded initially and subsequently at 28-day intervals for a total of 140 days to evaluate ADG. Dry matter intake (DMI) was recorded daily. Feed efficiency was calculated per period.

Feed and refusal samples were taken daily and composited for each period. Samples were ground in a Wiley mill (1-mm screen; Wiley mill model 4, Thomas Scientific, Swedesboro, NJ) and subjected to all or part of the following analysis: DM, organic matter, and CP (methods numbers 930.15, 942.15, and 990.02, respectively; AOAC, 2003). Acid detergent fiber (ADF) and neutral detergent fiber (NDF) were determined sequentially according to Van Soest et al. (1991) using an Ankom 200 fiber analyzer (Ankom Technology, Fairport, NY).

Digestibility of DM, CP, and NDF was evaluated. At the end of the performance trial, ten steers per treatment were randomly selected and kept outdoors in the pens used for the performance trial $\left(13 \mathrm{~m}^{2}\right)$. The same schedule and feeding regime were followed. The digestibility trial consisted of three days of fecal sample collection. During collection, fecal samples were taken directly from the rectum four times daily as follows: day $1-08: 00,10: 00,12: 00$, and 14:00 h; day 2 - 16:00, 18:00, 20:00, and 22:00 h; and day 3 - 00:00, 02:00, 04:00, and 06:00 h (Castillo Rangel et al., 2017). Individual fecal samples weighed approximately $50 \mathrm{~g}$ (wet basis). Samples for each animal were composited for analysis and stored at $-20^{\circ} \mathrm{C}$.

Composited fecal samples were dried in a forcedair oven at $60{ }^{\circ} \mathrm{C}$ for five days. Feed, refusals, and fecal samples were ground in a Wiley mill (1-mm screen) and analyzed for DM, CP, ADF, and NDF as described previously. Feed and fecal samples were incubated in the rumen of cannulated heifers (Huhtanen et al., 1994). After incubation, bags were washed four times with cold water for $5 \mathrm{~min}$ and then dried $\left(60^{\circ} \mathrm{C}\right)$ for $24 \mathrm{~h}$. The concentration of ADF remaining in the bag residue was determined to calculate the percentage of insoluble acid detergent fiber (IADF; Penning and Johnson, 1983).
Apparent DM digestibility was predicted using IADF according to the following formula (Schneider and Flatt, 1975):

$$
\mathrm{DMD}=100-\left[100 \times\left(\frac{\% \mathrm{IADF} \text { in feed }}{\% \text { IADF in feces }}\right)\right]
$$

Apparent digestibility of CP and NDF were calculated using the formula:

Nutrient digestibility $(\mathrm{ND})=100-\left[100 \times\left(\frac{\% \text { IADF in feed }}{\% \text { IADF in feces }} \times \frac{\% \text { of nutrient in feces }}{\% \text { of nutrient in feed }}\right)\right]$

Data for ADG, DMI, and G:F were analyzed via a completely randomized design, with measurements repeated over time using the MIXED procedure of SAS (Statistical Analysis System, version 9.1.3). Animals were the experimental units. When significant $(\mathrm{P}<0.05)$ F-statistics were noted, means were separated using least square differences method.

The mathematical model was:

$$
\mathrm{Y}_{\mathrm{ijk}}=\mu+\tau_{\mathrm{i}}+\mathrm{d}_{\mathrm{j}}+\mathrm{i}_{\mathrm{k}}\left(\tau_{\mathrm{i}}\right)+\Theta_{\mathrm{ij}}+\mathrm{e}_{\mathrm{ijk}},
$$

in which $Y_{\mathrm{ijk}}=$ observed value of the variable that received the treatment; $\mu=$ overall mean; $\tau_{\mathrm{i}}=$ effect of treatment; $\mathrm{d}_{\mathrm{j}}=$ effect of the day of measurement; $\mathrm{i}_{\mathrm{k}}\left(\tau_{\mathrm{i}}\right)=$ effect of animal within treatment; $\Theta_{\mathrm{ij}}=$ effect of the interaction between treatment and day; and $\mathrm{e}_{\mathrm{ijk}}=$ random error associated with each observation.

Data concerning the digestibility of DM, CP, and NDF were analyzed via a completely randomized design using the GLM procedure. Animals were the experimental units. When significant $(\mathrm{P}<0.05) \mathrm{F}$-statistics were noted, means were separated using least square differences method.

The mathematical model was:

$$
\mathrm{Y}_{\mathrm{ij}}=\mu+\tau_{\mathrm{i}}+\mathrm{e}_{\mathrm{ij}} \text {, }
$$

in which $Y_{i j}=$ observed value of the variable that received the treatment; $\mu=$ overall mean; $\tau_{\mathrm{i}}=$ effect of treatment; and $\mathrm{e}_{\mathrm{ij}}=$ random error associated with each observation.

\section{Results}

For DMI, no differences $(\mathrm{P}>0.05)$ were found between treatments. No interaction $(\mathrm{P}>0.05)$ between treatment and day was found. At the end of the trial, ADG was greater $(\mathrm{P}<0.05)$ for the control group, although no effect $(\mathrm{P}>0.05)$ for $\mathrm{G}: \mathrm{F}$ was found. For the apparent digestibility of DM, $\mathrm{CP}$, and NDF, no differences $(\mathrm{P}>0.05)$ were found between treatments. Due to the equal DMI and similar digestibility, digestible dry matter intake (DDMI), digestible crude protein intake (DCPI), and digestible neutral detergent fiber intake (DNDFI) were similar $(\mathrm{P}>0.05)$ between treatments. 


\section{Discussion}

The diets used in the present experiment are common for feedlot cattle in the central and northern parts of Mexico. The results of the present experiment are consistent with other authors. Different studies did not find variations in DMI when steers received probiotics in the diet (Vasconcelos et al. 2008; Stephens et al., 2010; Narvaez et al. 2014; Cull, et al., 2015; Kenney et al., 2015; Wilson et al., 2016). In these studies, additives based only on probiotics were provided (lactate acidproducing bacteria, lactate acid-utilizing bacteria, or both in combination). In those experiments, bacteria such as Enterococcus faecium, Lactobacillus acidophilus, and Propionibacterium freudenreichii were the primary cultures used. Similar results for DMI were reported by Swyers et al. (2014) when Saccharomyces cerevisiae was used in feedlot cattle. These authors attributed the similarities to animal discomfort during the experiment compared with studies in which animals were not subjected to stressful factors. During this experiment, steers were exposed to constant rain, which produced stress and had an impact on animal performance. These stress factors should be an effect in which the DFM could improve animal performance, due to an increase in fiber digestibility. Yeast feeding is a common practice in feedlot reception for both steers and heifers due to the resulting improvement in DMI (Lesmeister et al., 2004) and the positive impact on ruminal microbiota, increasing dry matter digestibility (Brown and Nagaraja, 2009), and reducing the effect of stress. In the present experiment, steers were adapted to the feedlot management at the beginning of the experiment. It is assumed that DFM did not have an impact on ruminal microbiota. Conversely, Ponce et al. (2011) reported an improvement in DMI and ADG when heifers fed in feedlot received diets with a mixture of lactate acid-producing bacteria and digestive enzymes, which differ from the results of the present experiment. There are similarities between the results of this study and the work of Stephens et al. (2010), in which a combination of Lactobacillus acidophilus and Saccharomyces cerevisiae was given to feedlot cattle and led to no differences reported between a group using DFM and a control group for DMI, ADG, and G:F. When enzymes such as amylase were added to the additive used in this study, an improvement in nutrient digestibility was expected. Due to this improvement, an improvement in animal performance was also expected. Nonetheless, DFM did not lead to better performance. The data presented here agree with those reported by Krehbiel et al. (2003), who concluded that the response of animals that received DFM is inconsistent for DMI.

As mentioned above, similar ADG between treatments for each period was obtained. However, an unexpectedly higher ADG was obtained in the control group at the end of the trial and associated with the tendency towards higher DMI for this group (Table 3). The reason for a reduced ADG in animals of the group fed DFM is not clear. Similar results were shown by Swyers et al. (2014), who found a reduction in ADG in steers receiving Saccharomyces cerevisiae during 125 days of a finishing feedlot diet; they reported that stress factors were not present during the experiment. The conditions differed from those of this study, in which the presence of mud represented a stress factor for a long period of time during the experiment. Ponce et al. (2011) reported a greater ADG in steers with diets supplemented by a mixture of lactate acid-producing bacteria and digestive enzymes for 140 days in the feedlot compared with a control group. To our knowledge, information about the effect of using DFM-enzyme mixtures is limited. It was assumed that their use would increase nutrient digestibility, which could in turn improve animal performance, but a different effect was found. The use of DFM usually increases nutrient digestibility in animals fed diets with high content of fiber, which differ

Table 3 - Performance of steers fed diet supplemented or not with direct-fed microbials (DFM)

\begin{tabular}{|c|c|c|c|c|}
\hline Item & Control & DFM $^{1}$ & SEM & P-value \\
\hline \multicolumn{5}{|c|}{ DMI (kg/day) } \\
\hline $1-28$ & $9.79 a$ & $9.20 \mathrm{a}$ & 0.39 & 0.281 \\
\hline $29-56$ & $11.76 \mathrm{a}$ & $11.29 \mathrm{a}$ & 0.39 & 0.386 \\
\hline $57-84$ & $12.36 \mathrm{a}$ & $11.82 \mathrm{a}$ & 0.40 & 0.338 \\
\hline $85-112$ & $12.10 \mathrm{a}$ & $11.42 \mathrm{a}$ & 0.40 & 0.227 \\
\hline $113-140$ & $11.77 \mathrm{a}$ & $11.64 \mathrm{a}$ & 0.40 & 0.810 \\
\hline Average & $11.56 \mathrm{a}$ & $11.07 \mathrm{a}$ & 0.31 & 0.284 \\
\hline \multicolumn{5}{|c|}{ ADG (kg) } \\
\hline $1-28$ & $2.30 \mathrm{a}$ & $1.83 \mathrm{~b}$ & 0.12 & 0.005 \\
\hline $29-56$ & $2.00 \mathrm{a}$ & $1.88 \mathrm{a}$ & 0.12 & 0.485 \\
\hline $57-84$ & $1.79 \mathrm{a}$ & $1.82 \mathrm{a}$ & 0.12 & 0.874 \\
\hline $85-112$ & $1.77 \mathrm{a}$ & $1.45 \mathrm{a}$ & 0.12 & 0.065 \\
\hline $113-140$ & $0.94 \mathrm{a}$ & $0.82 \mathrm{a}$ & 0.12 & 0.486 \\
\hline Average & $1.76 \mathrm{a}$ & $1.56 \mathrm{~b}$ & 0.06 & 0.026 \\
\hline \multicolumn{5}{|l|}{$\mathrm{G}: \mathrm{F}$} \\
\hline $1-28$ & $0.233 \mathrm{a}$ & $0.200 \mathrm{~b}$ & 0.01 & 0.018 \\
\hline $29-56$ & $0.172 \mathrm{a}$ & $0.168 \mathrm{a}$ & 0.01 & 0.806 \\
\hline $57-84$ & $0.143 \mathrm{a}$ & $0.152 \mathrm{a}$ & 0.01 & 0.535 \\
\hline $85-112$ & $0.146 a$ & $0.127 \mathrm{a}$ & 0.01 & 0.182 \\
\hline $113-140$ & $0.078 \mathrm{a}$ & $0.065 \mathrm{a}$ & 0.01 & 0.355 \\
\hline Average & $0.154 \mathrm{a}$ & $0.143 a$ & 0.01 & 0.114 \\
\hline
\end{tabular}

DMI - dry matter intake; ADG - average daily gain; G:F - feed efficiency; SEM standard error of the mean.

${ }^{1}$ Effect of the addition of a mixture of DFM, yeast, and digestive enzymes.

Means in the same row with different superscripts are significantly different $(\mathrm{P}<0.05)$. 
from the conditions of the present experiment. Similar results have been reported by several other authors, who did not find differences in ADG between treatments as a result of DFM use in animal feeding (Neuhold et al., 2012; Narvaez et al., 2014; Cull et al., 2015; Kenney et al., 2015).

Reports for G:F are not consistent. Ponce et al. (2011) found similar $G: F$ when feedlot cattle received a mixture of DFM and digestive enzymes (amylase, proteases, hemi-cellulases, phytase, cellulose, lipase, pectinase, and glucanase), and results were compared with a control group; these results are in agreement with our experiment. Additionally, recent studies have not found improvements in G:F associated with use of DFM (Neuhold et al., 2012; Narvaez et al., 2014; Kenney et al., 2015; Wilson et al., 2016). Similarly, when Saccharomyces cerevisiae (Swyers et al., 2014; Carrasco et al., 2016), or its combination with Lactobacillus acidophilus (Stephens et al., 2010) were given as supplements to feedlot cattle, these supplementations did not have an effect on G:F. However, Aydin et al. (2009) reported an increase in G:F when Holstein steers received a combination of DFM and digestive enzymes. Vasconcelos et al. (2008) and Cull et al. (2015) added Lactobacillus acidophilus and Propionibacterium freudenreichii to a feedlot cattle diet and reported an associated improvement in G:F. Krehbiel et al. (2003) reported that the use of DFM increased ADG and G:F at levels of 5 and $2.5 \%$, respectively, compared with a control group. Due to the inconsistency in the literature, it is recommended that for the use of DFM in ruminant feeding, one should consider factors such as health status, stress factors, diets, and dosage, among others.

In contrast, Tricarico et al. (2007) supplemented amylase in a diet for feedlot steers and found no increase in G:F, which is in agreement with the results found in this experiment. In this study, due to the characteristics of the supplement, it was expected that the use of DFM, yeast, and digestive enzymes might increase digestibility of DM, CP, and NDF, which could have an impact on animal performance. Similar results have been reported when Lactobacillus acidophilus and Enterococcus faecium (Kenney et al., 2015), Enterococcus faecium or its combination with Saccharomyces cerevisiae (Beauchemin et al., 2003), Saccharomyces cerevisiae (Monnert et al., 2013), Enterococcus faecium and Propionibacterium (Ghorbani et al., 2002), and a mixture of lactate acid-producing bacteria and digestive enzymes (Ponce et al., 2011) were supplemented to diets of feedlot cattle; however, this research reported no differences in nutrient digestibility compared with a control group (Table 4). To our knowledge, information
Table 4 - Nutrient digestibility and their intake by steers supplemented with and without direct-fed microbials (DFM)

\begin{tabular}{lcccc}
\hline Item & Control & DFM $^{1}$ & SEM & P-value \\
\hline Aparent DMD $\left(\mathrm{g} \mathrm{kg}^{-1}\right.$ of DM) & 830.47 & 834.11 & 1.109 & 0.819 \\
Aparent CPD $\left(\mathrm{g} \mathrm{kg}^{-1}\right.$ of DM) & 769.31 & 774.81 & 1.354 & 0.777 \\
Aparent NDFD $\left(\mathrm{g} \mathrm{kg}^{-1}\right.$ of DM) & 543.59 & 558.85 & 3.223 & 0.741 \\
Digestible DMI $\left(\mathrm{g} \mathrm{kg}^{-1}\right.$ of DM) & 87.48 & 91.69 & 0.520 & 0.574 \\
Digestible CPI $\left(\mathrm{g} \mathrm{kg}^{-1}\right.$ of DM) & 8.13 & 8.542 & 0.050 & 0.571 \\
Digestible NDFI $\left(\mathrm{g} \mathrm{kg}^{-1}\right.$ of DM $)$ & 9.90 & 10.64 & 0.066 & 0.445 \\
\hline
\end{tabular}

DM - dry matter; DMD - dry matter digestibility; CPD - crude protein digestibility; NDFD - neutral detergent fiber digestibility; DMI - dry matter intake; CPI crude protein intake; NDFI - neutral detergent fiber intake; SEM - standard error of the mean.

${ }^{1}$ Effect of the addition of a mixture of DFM and digestive enzymes.

related to digestible $\mathrm{DM}$ intake, digestible $\mathrm{CP}$ intake, and digestible NDF intake is not yet available. Due to the relationship between DMI and nutrient digestibility, the supplementation of this study was expected to increase the availability of nutrients for the ruminant and, consequently, to markedly improve animal performance; these results were not found.

\section{Conclusions}

Supplementing feedlot cattle diets with a mixture of direct-fed microbials and digestive enzymes does not improve animal performance and nutrient digestibility. Its use for finishing feedlot cattle is not recommended.

\section{Acknowledgments}

Appreciation is expressed to DCM Nutrition \& Pharma S. A. de C. V., for its financial support.

\section{References}

AOAC - Association of Official Analytical Chemistry. 2003. Official methods of analysis. 17th ed. AOAC International, Arlington, VA.

Avendaño-Reyes, L.; Torres-Rodríguez, V.; Meraz-Murillo, F. J.; Pérez-Linares, C.; Figueroa-Saavedra, F. and Robinson, P. H. 2006. Effects of two B-adrenergic agonists on finishing performance, carcass characteristics, and meat quality of feedlot steers. Journal of Animal Science 84:3259-3265.

Aydin, R.; Mete, Y.; Kocyigit, R.; Diler, A. and Ozkilicci, T. 2009. Effect of direct-fed microbials plus enzyme supplementation on the fattening performance of Holstein young bulls at two different initial body weights. African Journal and Agricultural Research 4:548.

Beauchemin, K. A.; Yang, W. Z.; Morgavi, D. P.; Ghorbani, G. R.; Kautz, W. and Leedle, J. A. Z. 2003. Effects of bacterial direct- fed microbials and yeast on site and extent of digestion, blood chemistry, and subclinical ruminal acidosis in feedlot cattle. Journal of Animal Science 81:1628-1640. https://doi.org/ $10.2527 / 2003.8161628 x$ 
Brown, M. S. and Nagaraja, T. G. 2009. Direct-fed microbials for growing and finishing cattle. p.42-61. In: Proceedings of the Plains Nutrition Council. Spring Conference. Publication No. AREC 09-18, Texas AgriLife Research and Extension Center, Amarillo.

Bryant, T. C.; Engle, T. E.; Galyean, M. L.; Wagner, J. J.; Tatum, J. D.; Anthony, R. V. and Laudert, S. B. 2010. Effects of ractopamine and trenbolone acetate implants with or without estradiol on growth performance, carcass characteristics, adipogenic enzyme activity, and blood metabolites in feedlot steers and heifers. Journal of Animal Science 88:4102-4119. https://doi.org/10.2527/jas.2010-2901

Carrasco, C.; Medel, P.; Fuentetaja, A.; Ranilla, M. J. and Carro, M. D. 2016. Effect of disodium/calcium malate or Saccharomyces cerevisiae supplementation on growth performance, carcass quality, ruminal fermentation products, and blood metabolites of heifers. Journal of Animal Science 94:4315-4325. https://doi.org/ 10.2527/jas.2016-0616

Castillo Rangel, F.; Villalobos Villalobos, G.; Domínguez Díaz, D. and Ortega Gutiérrez. J. A. 2017. Dietary level of cull pinto beans on nutrient digestibility and animal performance of finishing hair lambs. Revista Brasileira de Zootecnia 46:400-404. https://doi.org/10.1590/s1806-92902017000500005

Cull, C. A.; Renter, D. G.; Bello, N. M.; Ives, S. E. and Babcock, A. H. 2015. Performance and carcass characteristics of commercial feedlot cattle from a study of vaccine and direct-fed microbial effects on Escherichia coli O157:H7 fecal shedding. Journal of Animal Science 93:3144-3151. https://doi.org/10.2527/ jas.2015-8924

Elam, N. A.; Gleghorn, J. F.; Rivera, J. D.; Galyean, M. L.; Defoor, P. J.; Brashears, M. M. and Younts-Dahl, S. M. 2003. Effects of live culture of Lactobacillus acidophilus (strains NP45 and NP51) and Propionibacterium freudenreichii on performance, carcass, and intestinal characteristics, and Escherichia coli strain O157 shedding of finishing beef steers. Journal of Animal Science 81:2686-2698.

Fuller, R. 1989. A review: probiotics in man and animals. Journal of Applied Bacteriology 66:365-378. https:// doi.org/10.1111/j.1365-2672.1989.tb05105.x

Galyean, M. L.; Nunnery, G. A.; Defoor, P. J.; Salyer, G. B. and Parsons, C. H. 2000. Effects of live cultures of Lactobacillus acidophilus (Strains 45 and 51) and Propionibacterium freudenreichii PF-24 on performance and carcass characteristics of finishing beef steers. In: Burnett Center Internet Progress Report No 8. Lubbock, Texas, United States of America.

Ghorbani, G. R.; Morgavi, D. P.; Beauchemin, K. A. and Leedle, J. A. Z. 2002. Effects of bacterial direct-fed microbials on ruminal fermentation, blood variables, and the microbial populations of feedlot cattle. Journal of Animal Science 80:1977-1986.

Huhtanen, P.; Kaustell, K. and Jaakkola, S. 1994. The use of internal markers to predict total digestibility and duodenal flow of nutrients in cattle given six different diets. Animal Feed Science and Technology 48:211-227. https://doi.org/10.1016/03778401(94)90173-2

Kenney, N. M.; Vanzant, E. S.; Harmon, D. L. and McLeod, K. R. 2015. Direct-fed microbials containing lactate-producing bacteria influence ruminal fermentation but not lactate utilization in steers fed a high-concentrate diet. Journal of Animal Science 93:2336-2348. https://doi.org/10.2527/jas.2014-8570

Kmet, V.; Flint, H. J. and Wallace, R. J. 1993. Probiotics and manipulation of rumen development and function. Archives of Animal Nutrition 44:1-10. https://doi.org/10.1080/17450399309386053

Krehbiel, C. R.; Rust, S. R.; Zhang, G. and Gilliland, S. E. 2003. Bacterial direct fed microbials in ruminant diets: Performance response and mode of action. Journal of Animal Science 81(E-Suppl. 2):E120-E132.
Lesmeister, K. E.; Henrich, A. J. and Gabler, M. T. 2004. Effects of supplemental yeast (Saccharomyces cerevisiae) culture on rumen development, growth characteristics and blood parameters in neonatal dairy calves. Journal of Dairy Science 87:1832-1839. https://doi.org/10.3168/jds.S0022-0302(04)73340-8

Martin, S. A. and Nisbet, D. J. 1992. Effect of direct-fed microbials on rumen microbial fermentation. Journal of Dairy Science 75:17361744. https://doi.org/10.3168/jds.S0022-0302(92)77932-6

Monnert, J. P. I. S.; Paulino, P. V. R.; Detmann, E.; Valadares Filho, S. C.; Valadares, R. D. F. and Duarte, M. S. 2013. Effects of Saccharomyces cerevisiae and monensin on digestion, ruminal parameters, and balance of nitrogenous compounds of beef cattle fed diets with different starch concentrations. Tropical Animal Health and Production 45:1251-1257. https://doi.org/10.1007/s11250-013-0356-9

Narvaez, N.; Alazzeh, A. Y.; Wang, Y. and McAllister, T. A. 2014. Effect of Propionibacterium acidipropionici P169 on growth performance and rumen metabolism of beef cattle fed a corn- and corn dried distillers' grains with solubles-based finishing diet. Canadian Journal of Animal Science 94:363-369. https://doi.org/10.4141/cjas2013-130

Neuhold, K. L.; Wagner, J. J.; Archibeque, S. L.; Engle, T. E. and Kreikemeier, K. K. 2012. An evaluation of $10-\mathrm{G}$ brand directfed microbial for yearling steers fed finishing diets containing wet distillers grains. Professional Animal Scientist 28:319-324. https://doi.org/10.15232/S1080-7446(15)30362-4

Newbold, C. J.; Wallace, R. J. and McIntosh, F. M. 1996. Mode of action of the yeast Saccharomyces cerevisiae as a feed additive for ruminants. British Journal of Nutrition 76:249-261. https://doi.org/10.1079/BJN19960029

Norma Oficial Mexicana NOM-024-ZOO-1995. Especificaciones y características zoosanitarias para el transporte de animales, sus productos y subproductos, productos químicos, farmacéuticos biológicos y alimenticios para su uso en animales o consumo por éstos. Diario Oficial de la Federación. 16 octubre 1995.

Norma Oficial Mexicana NOM-051-ZOO-1995. Trato humanitario en la movilización de animales. Diario Oficial de la Federación. 23 marzo 1996.

NRC - National Research Council. 2000. Nutrient requirements of beef cattle. 7th rev. ed. National Academy Press, Washington, DC.

Penning, P. D. and Johnson, R. H. 1983. The use of internal markers to estimate herbage intake and digestibility. 1. Indigestible acid detergent fiber. Journal of Agricultural Science 100:133-138.

Phelps, K. J.; Drouillard, J. S.; Jennings, J. S.; Depenbusch, B. E.; Vaughn, M. A.; Burnett, D. D.; Ebarb, S. M.; Dietz, G. J.; Heitschmidt, J. D.; Noel, J. A, Houser, T. A. and Gonzalez, J. M. 2015. Effect of the Programmed Nutrition Beef Program on moisture retention of cooked ground beef patties and enhanced strip loins. Meat Science 100:189-194. https://doi.org/10.1016/j.meatsci.2014.10.021

Ponce, C. H.; DiLorenzo, N.; Quinn, M. J.; Smith, D. R.; May, M. L. and Galyean, M. L. 2011. Case study: Effects of a direct-fed microbial on finishing beef cattle performance, carcass characteristics, and in vitro fermentation. Professional Animal Scientist 27:276-281. https://doi.org/10.15232/S1080-7446(15)30485-X

Schneider, B. H. and Flatt, W. P. 1975. Evaluation of feed trough digestibility experiments. University of Georgia Press, Athens, GA, USA.

Scollan, N.; Hocquette, J. F.; Nuernberg, K.; Dannenberger, D.; Richardson, I. and Moloney, A. 2006. Innovations in beef production systems that enhance the nutritional and health value of beef lipids and their relationship with meat quality. Meat Science 74:17-33. https://doi.org/10.1016/j.meatsci.2006.05.002 
Seo, J. K.; Kim, S. W.; Kim, M. H.; Upadhaya, S. D.; Kam, D. K. and Ha, J. K. 2010. Direct-fed microbials for ruminant animals. Asian-Australasian Journal of Animal Sciences 23:1657-1679. https://doi.org/10.5713/ajas.2010.r.08

Stephens, T. P.; Stanford, K.; Rode, L. M.; Booker, C. W.; Vogstad, A. R.; Schunicht, O. C.; Jim, G. K.; Wildman, B. K.; Perrett, T. and McAllister, T. A. 2010. Effect of a directfed microbial on animal performance, carcass characteristics and the shedding of Escherichia coli $\mathrm{O} 157$ by feedlot cattle. Animal Feed Science and Technology 158:65-72. https://doi.org/10.1016/j.anifeedsci.2010.04.007

Swyers, K. L.; Wagner, J. J.; Dorton, K. L. and Archibeque, S. L. 2014. Evaluation of Saccharomyces cerevisiae fermentation product as an alternative to monensin on growth performance, cost of gain, and carcass characteristics of heavy-weight yearling beef steers. Journal of Animal Science 92:2538-2545. https://doi.org/10.2527/jas.2013-7559

Thompson, A. J.; Smith, Z. K. F.; Corbin, M. J.; Harper, L. B. and Johnson, B. J. 2016. Ionophore strategy affects growth performance and carcass characteristics in feedlot steers. Journal of Animal Science 94:5341-5349. https://doi.org/10.2527/jas.2016-0841

Tricarico, J. M.; Abney, M. D.; Galyean, M. L.; Rivera, J. D.; Hanson, K. C.; McLeod, K. R. and Harmon, D. L. 2007. Effects of a dietary Aspergillus oryzae extract containing $\alpha$-amylase activity on performance and carcass characteristics of finishing beef cattle. Journal of Animal Science 85:802-811. https://doi.org/10.2527/jas.2006-427

Van Soest, P. J.; Roberston, J. and Lewis, B. A. 1991. Methods for dietary fiber, neutral detergent fiber and nonstarch polysaccharides in relation to animal nutrition. Journal of Dairy Science 74:35833597. https://doi.org/10.3168/jds.S0022-0302(91)78551-2

Vasconcelos, J. T.; Elam, N. A.; Brashears, M. M. and Galyean, M. L. 2008. Effects of increasing dose of live cultures of Lactobacillus acidophilus (Strain NP 51) combined with a single dose of Propionibacterium freudenreichii (Strain NP 24) on performance and carcass characteristics of finishing beef steers. Journal of Animal Science 8:756-762. https://doi.org/10.2527/jas.2007-0526

Wilson, B. K.; Holland, B. P.; Step, D. L.; Jacob, M. E.; VanOverbeke, D. L.; Richards, C. J.; Nagaraja, T. G. and Krehbiel, C. R. 2016. Feeding wet distillers grains plus solubles with and without a direct-fed microbial to determine performance, carcass characteristics, and fecal shedding of Escherichia coli O157:H7 in feedlot heifers. Journal of Animal Science 94:297-305. https://doi.org/10.2527/jas.2015-9601

Yoon, I. K. and Stern, M. D. 1995. Influence of direct-fed microbials on ruminal microbial fermentation and performance of ruminants: a review. Asian-Australasian Journal of Animal Sciences 8:533-555. https://doi.org/10.5713/ajas.1995.553 